\title{
Architectural and authentic
}

'Linking practice with research' is both our cover slogan and our objective. arq covers the broad spectrum of architectural endeavour - which comes together in design and buildings - and publishes contributions from both academics and practitioners. Take this issue.

First, it covers and considers architectural research in many forms and ways. There's Rem Koolhaas' research on shopping; a pioneering application of a passive environmental system; a competition-winning scheme for new housing; an account of a completely unknown project by Le Corbusier; and an introduction to an alternative to air-conditioning in hot, dry climates. There's also a timely look back towards the beginnings of university-based architectural research in the 196os; the first English translation of Freyssinet's remarkable essay on the sublime; and a review of Zaha Hadid's recent work and its theoretical base.

Second, each of this broad spread of topics is design and practice-related. Most of the authors have academic affiliations but seven are also architects in practice and one is a practising engineer. Just two are architectural historians. Two of the articles - those on the design of the Jersey Archive and on passive downdraught evaporative cooling are interdisciplinary and based on considerations of sustainability. Our letters pages reveal a bias towards practice - but, although all our correspondents are practising architects or engineers, most have strong connections with academia.

But this issue takes things a step further: it is the very first arq to carry an article directly based on an architect's drawings and design report - rather than on a piece especially written for publication. 'From table to basin: St Mary's Island' (pp. 229-247) is a lightly edited version of a competition-winning entry for a large 'brownfield' site in South-East England. For many years, there have been very few competitions of this kind. The Editors felt that Buschow Henley's scheme deserved more coverage than it had enjoyed in the professional press. Our referees agreed and made just one recommendation - that the architects should write a short introduction outlining their theoretical position.

In our second issue, in the middle of a lively debate then being conducted in our pages (arq $1 / 1$ and 2), Philip Tabor wrote a leader entitled 'Design is research: is it?' He asked whether 'a design submission, entirely drawn and unaccompanied by text, would be awarded a research degree in architecture? Or, closer to home, would arq's editor and referees, accept it for publication?' The answer he concluded, was 'Probably not.' Six years on, 'From table to basin' represents a shift in editorial policy and a demonstration of the way in which designers can reflect upon their work as research in a way that journalists cannot. 


\section{architectural research quarterly}

\section{Subscribe now for 2002}

Innovative in conception, unique in breadth and generously illustrated, this pace-setting quarterly publication from Cambridge University Press links, on a global scale, the worlds of architectural practice and research. arq regularly includes extensive peer-reviewed sections on design, history, theory, construction, environmental design, information technology and practice - as well as structures, urbanism and documents. These are supplemented by letters, reports, reviews, a directory of specialist research centers and consultancies and an annual index. Each issue opens with a leader and closes with insight, a personal end-piece. In its three year history, arq has published work from all over the world: from Chile to Sweden and from Japan to the Netherlands - with a strong representation from the United Kingdom and United States. arq, like architecture itself, is all-embracing and written by and for both practitioners and academics. It provides an outlet for all those who wish to disseminate

their work to an international audience.
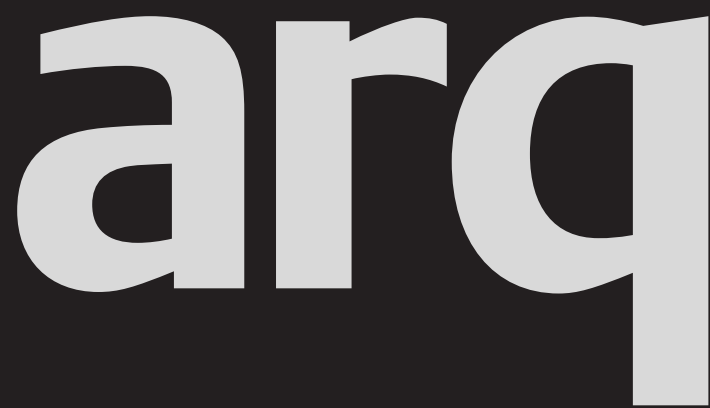

Please enter my subscription to

arq: architectural research quarterly, volume 6, 2002

$$
\begin{aligned}
& \text { £110/\$174 institutions print and electronic } \\
& \text { £28/\$46 students } \\
& £ 41 / \$ 63 \text { individuals print only }
\end{aligned}
$$

EU residents only. VAT may be payable at your local rate if not registered.

Our vat registration number: GB 214141614 If registered, your VAT registration no:

Total subscription payment $€ / \$$ Eu residents only, if not registered add VAT at appropriate rate

Canadian residents, add 7\% GST \$

Total $\mathbf{E} / \mathbf{S}$

Name

Address

\section{Payment enclosed}

Cheque in sterling or US dollars

(payable to Cambridge University Press)

Credit Card - VISA | MasterCard | American Express (delete where applicable)

Card no

Expiry date

Signature

Photocopy this page and send your order to:

Journals Customer Services, Cambridge University Press, The Edinburgh Building, Cambridge, CB2 2RU, UK

T $+44(0) 1223326070$

F +44 (o) 1223315052

E journals_subscriptions@cup.cam.ac.uk

or in USA, Canada and Mexico send to:

Cambridge University Press, 40 West 2oth Street,

New York NY 10011-4211, USA

T (914) 9379600

F (914) 9374712

E journals_subscriptions@cup.org 